\title{
A Mouse Model of Gyrate Atrophy of the Choroid and Retina Early Retinal Pigment Epithelium Damage and Progressive Retinal Degeneration
}

\author{
Tao Wang, ${ }^{\star}$ Ann H. Milam, ${ }^{\S}$ Gary Steel, ${ }^{\star}$ and David Valle ${ }^{\star \ddagger}$ \\ *Howard Hughes Medical Institute, ${ }^{\ddagger}$ Department of Pediatrics, The Johns Hopkins University School of Medicine, Baltimore, \\ Maryland 21205; and ${ }^{\S}$ Department of Ophthalmology, University of Washington School of Medicine, Seattle, Washington 98195
}

\begin{abstract}
Gyrate atrophy (GA) of the choroid and retina is a blinding chorioretinal degeneration caused by deficiency of ornithine $\delta$-aminotransferase (OAT). The phenotype of GA is characterized by progressive concentric reduction of the visual fields and ornithine accumulation. To understand better the pathogenesis of GA and to develop a model to test therapeutic strategies, we produced an OAT-deficient mouse by gene targeting. Like human GA patients, adult OAT-deficient mice exhibit chronic hyperornithinemia to levels 1015-fold above normal and massive ornithinuria. Slowly progressive retinal degeneration is reflected by a gradual decline in electroretinogram amplitudes over the first $\mathbf{1 2}$ mo of life. At $2 \mathrm{mo}$, the retinal pigment epithelium is histologically normal, but electron microscopy reveals sporadic degeneration of scattered pigment epithelial cells. By 6 mo there are more diffuse abnormalities of the pigment epithelium with accumulation of large phagosomes and crystalloid inclusions. Although morphologically normal at $2 \mathrm{mo}$, the photoreceptor outer segments become highly disorganized and shortened to $60 \%$ of control length by $10 \mathrm{mo}$. Additionally, there is cumulative loss of the photoreceptor cells, which reaches $33 \%$ by $10 \mathrm{mo}$ and is most pronounced in the central region of the retina. Our results indicate that retinal pigment epithelial cells are the initial site of insult in GA and that the OAT-deficient mouse is an excellent animal model of GA in human patients. (J. Clin. Invest. 1996. 97: 2753-2762.) Key words: ornithine $\delta$-aminotransferase $\bullet$ inborn error $\bullet$ ornithine $\bullet$ pathophysiology $\bullet$ histopathology
\end{abstract}

\section{Introduction}

First described as an "atypical retinitis pigmentosa" (1), gyrate atrophy (GA) ${ }^{1}$ of the choroid and retina is an autosomal recessive, blinding chorioretinal degeneration caused by a deficiency of ornithine $\delta$-aminotransferase (OAT). Clinically, GA

Address correspondence to David Valle, M.D., PCTB 802, Johns Hopkins University, 725 N. Wolfe Street, Baltimore, MD 21205. Phone: 410-955-4260; FAX: 410-955-7397; E-mail: david.valle@qmail. bs.jhu.edu

Received for publication 31 January 1996 and accepted in revised form 3 April 1996.

1. Abbreviations used in this paper: ERG, electroretinogram; GA, gyrate atrophy of the choroid and retina; OAT, ornithine $\delta$-aminotransferase; RPE, retinal pigment epithelium.

J. Clin. Invest.

(C) The American Society for Clinical Investigation, Inc.

0021-9738/96/06/2753/10 \$2.00

Volume 97, Number 12, June 1996, 2753-2762 patients initially develop myopia and reduced night vision, followed by gradual reduction in peripheral vision with constriction of the visual fields, leading to complete loss of vision at around the fourth to fifth decade of life (2-4). The presence of numerous sharply demarcated circular areas with hyperpigmented margins in the anterior to midperipheral retina is the earliest diagnostic funduscopic feature of GA. Over time, these lesions increase in number and size, coalesce, and spread from the peripheral to the central fundus. Complete loss of vision is associated with involvement of the macula. Electroretinography (ERG) abnormalities are present at an early stage of the disease, with impaired rod and cone responses ultimately progressing to a completely extinguished response (5-7). The biochemical and metabolic characteristics of GA have been studied extensively. Plasma ornithine levels are 10 15 -fold above normal, and lysine levels are reduced to $\sim 50 \%$ of normal (8-15). Deficient OAT activity has been documented in a variety of tissues from GA patients; about onethird of the patients have a small amount of residual activity $(<5 \%$ of normal $)$ and the remainder have no detectable OAT activity (14). The OAT cDNA and structural genes have been cloned and analyzed (16-18). More than 60 pathological mutations, most of which are point mutations resulting in either unstable or nonfunctional OAT, have been characterized in the OAT genes of GA patients $(14,19)$.

Despite the extensive understanding of GA at the metabolic, biochemical, and molecular levels, little is known about its pathogenesis; in particular, how the systemic metabolic abnormalities result in chorioretinal degeneration with only minimal involvement of other tissues (14). The low frequency of the disease, the slow progress of the chorioretinal degeneration, and the lack of opportunity for direct evaluation of affected retinal tissue all contribute to our lack of understanding of the pathogenesis of GA. The only reported retinal histopathologic study was performed on the eyes of a 98-yr-old patient with vitamin $\mathrm{B}_{6}$-responsive $\mathrm{GA}$ who had a small, isolated central area of functional retinal tissue surrounded by large areas totally devoid of choroidal and retinal layers (20). There was focal photoreceptor atrophy and hyperplasia of retinal pigment epithelial (RPE) cells in the region of demarcation between atrophic and relatively normal retina. Similar late stage retinal histopathology was described in an adult domestic cat with OAT deficiency (21). In a recent attempt to create an animal model of GA, Daune-Anglard et al. reduced OAT activity in adult mice to $10-20 \%$ of controls by chronic administration $(53 \mathrm{~d})$ of 5-fluoromethylornithine, a potent suicide inhibitor of OAT (22). The animals exhibited ornithine accumulation in tissues to levels $5-15$-fold above controls but failed to develop ERG abnormalities or a histologically detectable retinal degeneration during the 2-mo experiment.

To provide a model system for study of retinal pathophysiology and testing experimental therapies, we generated OATdeficient mice by targeted disruption of the murine OAT gene (23). Surprisingly, neonatal OAT-deficient $\left(\mathrm{Oat}^{-/-}\right)$mice ex- 
hibited severe hypoornithinemia, hypoargininemia, hypocitrullinemia, and hyperammonemia, leading to death 1-2 d after birth. This unexpected metabolic phenotype indicates that the net flux in the OAT reaction in neonatal mice is in the direction of ornithine synthesis rather than degradation. Ornithine is converted to the citrulline and arginine necessary for protein anabolism and urea cycle function in rapidly growing neonatal mice. Arginine supplementation, administered intraperitoneally every $12 \mathrm{~h}$ for the first $14 \mathrm{~d}$ of life, rescues $\mathrm{Oat}^{-/-}$ mice (23). After weaning, these animals develop profound hyperornithinemia, indicating that the net flux in the OAT pathway reverses. Preliminary evaluation indicated that retinal pathology developed in these mice over several months. In this report, we present a systematic characterization of this mouse model over 12 mo with particular emphasis on amino acid metabolism, electrophysiology, retinal histopathology, and ultrastructure.

\section{Methods}

Targeted disruption of the murine Oat gene. This work is described in detail in Wang et al. (23). In brief, we isolated a 13-kb EcoRI fragment containing exons $1-5$ of the murine Oat gene to make a replacement-type targeting construct with a neomycin resistance cassette inserted in exon 3 at codon 40. AB 1 (strain 129) cells with correct targeting events were identified by Southern blot analysis and microinjected into C57BL/6J blastocysts. Chimeric mice were bred with $\mathrm{C} 57 \mathrm{BL} / 6 \mathrm{~J}$ females to generate mice heterozygous and homozygous for the targeted Oat gene.

Animal husbandry. All animal breeding and manipulations were carried out according to National Institutes of Health guidelines at the Johns Hopkins University School of Medicine. Mice born from heterozygote matings were given intraperitoneal arginine at $12-\mathrm{h}$ intervals starting within hours after birth and continuing for the first 2 wk of life (23). The initial dose of arginine was $10 \mathrm{mmol} / \mathrm{kg}$ body wt per dose. The absolute amount administered remained constant, so, as the animals grew, the dose tapered to $\sim 2 \mathrm{mmol} / \mathrm{kg}$ body wt per dose at the end of the $2 \mathrm{wk}$. The arginine stock solution consisted of $1 \mathrm{M}$ arginine hydrochloride and $1 \mathrm{M}$ arginine-free base (Sigma Chemical Co., St. Louis, MO) at a ratio of 2:1 (vol/vol) with a final concentration of arginine of $1 \mathrm{M}$ and $\mathrm{pH}$ of $\sim 9$.

After weaning, the animals were maintained on standard rodent chow containing $\geq 20 \%$ protein (Mouse Diet 9F; PMI Feeds, Inc., Richmond, IN).

OAT enzyme assay. OAT activities from various mouse tissues were assayed radiochemically (19). The standard assay mixture contains $0.7 \mathrm{mM}$ l-ornithine, $0.7 \mathrm{mM} \alpha$-ketoglutarate, $50 \mu \mathrm{M}$ pyridoxal phosphate, $0.1 \mathrm{M} \mathrm{KPO}_{4}, \mathrm{pH} 8.0,0.10 \mu \mathrm{Ci}$ of $\left[{ }^{3} \mathrm{H}\right] 1$-ornithine (DuPontNew England Nuclear, Boston, MA), and $25-50 \mu \mathrm{g}$ of protein in a final volume of $250 \mu \mathrm{l}$. After incubation at $37^{\circ} \mathrm{C}$ for $0.5 \mathrm{~h}$, the reaction was terminated by adding $50 \mu \mathrm{l}$ of $6 \mathrm{~N} \mathrm{HCl}$. Under these conditions, the reaction product, glutamate semialdehyde, is converted nonenzymatically to pyrroline-5-carboxylate, which is separated from orni- thine by ion exchange chromatography on disposable 1-ml 100-200 mesh columns (Dowex AG 50W-X8 $\mathrm{H}^{+}$form; Bio-Rad Laboratories, Inc., Hercules, CA). Activities as low as $1 \mathrm{nmol}$ of product/h per $\mathrm{mg}$ of protein are detectable.

Plasma and urine amino acid analysis. Tail blood was collected from adult mice, and plasma was prepared using ammonium-free heparin (Sigma Chemical Co.) as an anticoagulant. Blood from newborn mice, obtained by direct heart puncture, was treated in the same way. An average of 30-50 $\mu$ l of plasma was obtained from each animal. Plasma amino acid determinations were made with an amino acid analyzer (model 6300; Beckman Instruments, Inc., Fullerton, CA). Urine was collected from adult mice by direct bladder puncture, and $50 \mu \mathrm{l}$ of each sample was used for amino acid analysis. Urine creatinine level was determined by a standard method (24).

ERG. Mouse ERGs were obtained with an EPIC-2000 system using a gold foil recording electrode in a dark environment (LKC Technologies Inc., Gaithersburg, MD) with minor modifications of a previously described method (25). $\mathrm{Oat}^{-/-}$mice and their agematched littermate controls were anesthetized using a mixture of $0.1 \%$ ketamine, $0.1 \%$ xylazine, and $4 \%$ urethane in Ringer's solution, $0.3 \mathrm{ml} / 20 \mathrm{~g}$ animal. The mice were subjected to $30 \mathrm{~min}$ of dark adaptation, and pupil dilation was achieved using $1 / 4$ drop of $0.25 \%$ tropicamide. A scotopic single flash light without filter $(0 \mathrm{~dB})$ was used as the source of light stimulation, and the maximal response from retina was recorded. Sixteen responses were averaged automatically with $5 \mathrm{~s}$ between stimuli, and mean latency and the amplitude of each ERG wave form were calculated.

Histology and electron microscopy. The mice were kept in a $12 \mathrm{~h}$ light $/ 12 \mathrm{~h}$ dark environment at an incident luminance of $<25$-footcandles. Eyes were enucleated from anesthetized $\mathrm{Oat}^{+/+}$and $\mathrm{Oat}^{-1-}$ mice (age 2,4,7, and $10 \mathrm{mo}$ ), immersion fixed in a mixture of $4 \%$ paraformaldehyde and $0.1 \%$ glutaraldehyde in $0.13 \mathrm{M}$ phosphate buffer, bisected along the vertical meridian, postfixed in $1 \% \mathrm{OsO}_{4}$ in phosphate buffer, and embedded in Medcast resin. 1- $\mu$ m-thick sections were stained with a mixture of toluidine blue, methylene blue, and basic fuchsin for light microscopy, and 90-nm sections were contrasted with uranyl acetate and lead citrate for electron microscopy. The extent of photoreceptor cell loss in the retinas was measured in well-oriented $1-\mu \mathrm{m}$ sections that included the optic nerve head and the superior and inferior ora serrata. Nuclei per cell column in the outer nuclear layer were counted at adjacent $250 \mu \mathrm{m}$ points along each retina, based on the method of LaVail (26), with each data point on the graph representing the mean of three counts. Outer segment lengths at the same points along the retinas were measured using an eyepiece micrometer.

Immunocytochemistry. Retinas from 4- and 10-mo-old $\mathrm{Oat}^{+/+}$ and $\mathrm{Oat}^{-/-}$mice were fixed for $6 \mathrm{~h}$ in $4 \%$ phosphate-buffered paraformaldehyde and stored in $10 \%$ phosphate-buffered sucrose. The eyes were bisected, and half of each eye was held in $30 \%$ sucrose in phosphate buffer overnight, cryosectioned at $12 \mu \mathrm{m}$, and processed for immunofluorescence (27). Antibodies used for immunolabeling were antirhodopsin (mouse mAb 4D2, 1:50, from Dr. R. Molday, University of British Columbia, Vancouver, BC, Canada); anti-red/ green cone opsin (rabbit polyclonal antibody, 1:200, from Dr. J. Saari, University of Washington, Seattle, WA); antiglial fibrillary acidic

Table I. OAT Activities in Tissues of Adult OAT-deficient and Control Mice

\begin{tabular}{|c|c|c|c|c|c|}
\hline \multirow[b]{2}{*}{ Oat genotype } & \multicolumn{5}{|c|}{ OAT activity (nmol product/h per $\mathrm{mg}$ )* } \\
\hline & Liver & Kidney & Small intestine & Muscle & Neural retina \\
\hline$+1+$ & $\begin{array}{c}163 \\
(143-183)\end{array}$ & $\begin{array}{c}422 \\
(400-444)\end{array}$ & $\begin{array}{c}290 \\
(279-331)\end{array}$ & $\begin{array}{c}42 \\
(38-47)\end{array}$ & $\begin{array}{c}94 \\
(93-97)\end{array}$ \\
\hline$-1-$ & nd & nd & nd & nd & nd \\
\hline
\end{tabular}

Tissues were collected from 2-3 pairs of OAT-deficient and control littermate adult mice. *Mean and range (in parenthesis). nd, not detectable. 
protein (rabbit polyclonal antibody, 1:400, Dako Corp., Carpinteria, CA). The secondary antibodies were labeled with Cy-3 (Jackson ImmunoResearch Laboratories, West Grove, PA), and control sections were processed with secondary antibody but omission of primary antibody. TdT UTP nick-end labeling (TUNEL) was performed on the opposite hemiretinas from the 4- and 10-mo-old $\mathrm{Oat}^{+/+}$and $\mathrm{Oat}^{-1-}$ mice according to the method of Gavrieli (28) and viewed en face as retinal flat mounts.

\section{Results}

Growth, development, and OATactivity. We generated Oat ${ }^{-1-}$ progeny from matings of mice heterozygous for the targeted Oat gene $\left(\mathrm{Oat}^{-1+}\right)$ and gave arginine supplementation to the $\mathrm{Oat}^{-1-}$ animals from a few hours after birth to the 14th postnatal day to prevent lethal hypoornithinemia and hypoarginine- mia (23). After weaning, we maintained these animals on standard rodent chow (see Methods). The growth rate, development, reproduction, and behavior of the $\mathrm{Oat}^{-1-}$ mice were indistinguishable from their $\mathrm{Oat}^{+/-}$and $\mathrm{Oat}^{+/+}$littermates (data not shown). Oat activity was not detectable in liver, small intestine, kidney, muscle, and retina in the $\mathrm{Oat}^{-/-}$mice, indicating that the targeted OAT allele was a null at the level of protein function (Table I).

Metabolic phenotype. There was a striking contrast in the plasma amino acid levels of neonatal and adult $\mathrm{Oat}^{-1-}$ mice (Fig. 1). In the neonates, the concentrations of ornithine, arginine, and citrulline are subnormal and there is accumulation of ammonium (23) (Fig. 1). After the second postnatal week, plasma ornithine rises rapidly, stabilizing at a level 10-15-fold higher than littermate controls, which is maintained over the ensuing 12 mo (Fig. $1 \mathrm{~A}$ ). There is no difference in the orni-
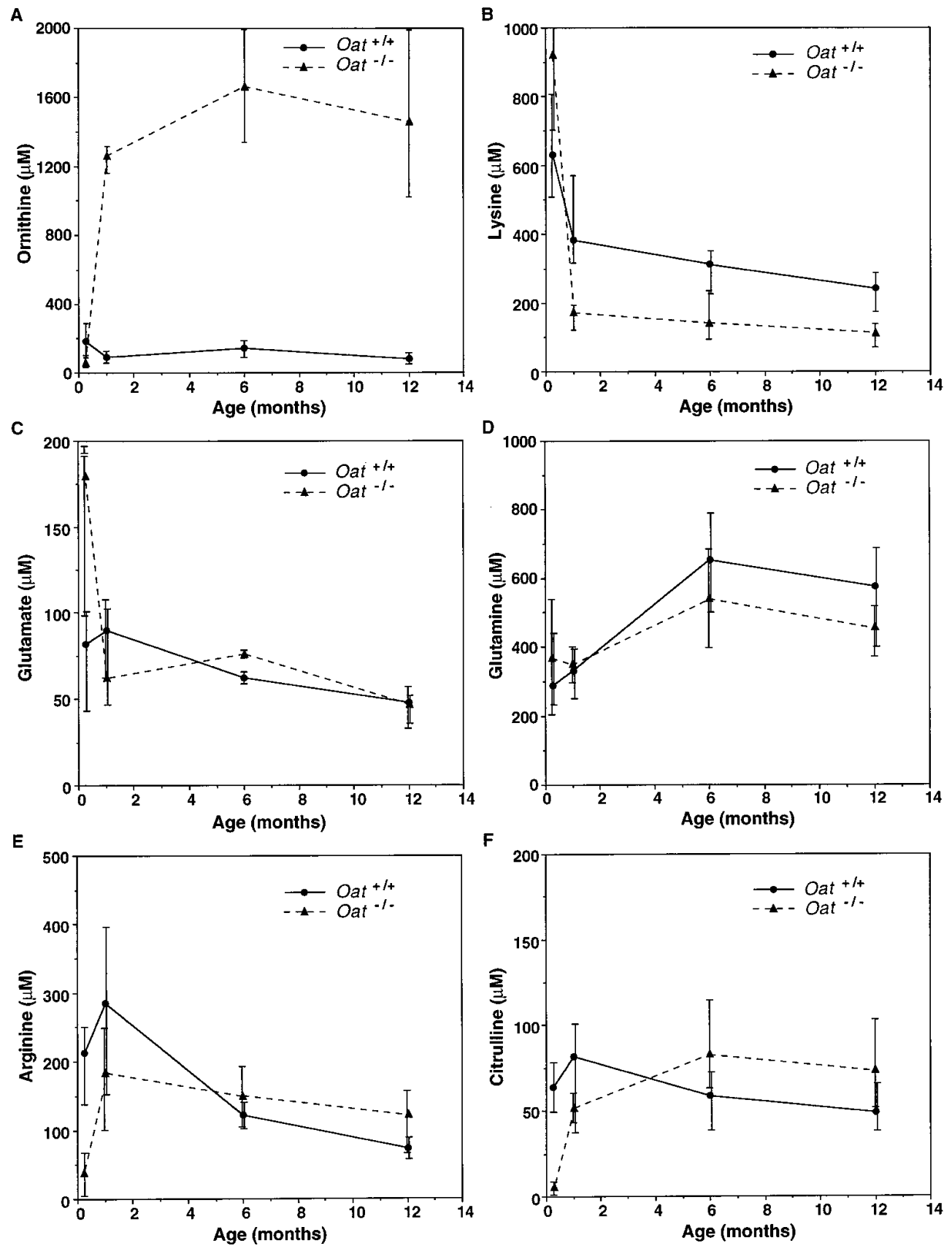

Figure 1. Selected plasma amino acid concentrations in $\mathrm{Oat}^{+/+}$and $\mathrm{Oat}^{-/-}$mice over 12 mo: $(A)$ ornithine, $(B)$ lysine, $(C)$ glutamic acid, $(D)$ glutamine, $(E)$ arginine, and $(F)$ citrulline. The mean and range for each amino acid (five to nine animals) is indicated by a filled circle and vertical bars for $\mathrm{Oat}^{+/+}$and by a filled triangle and vertical bars for $\mathrm{Oat}^{-1-}$ mice. 


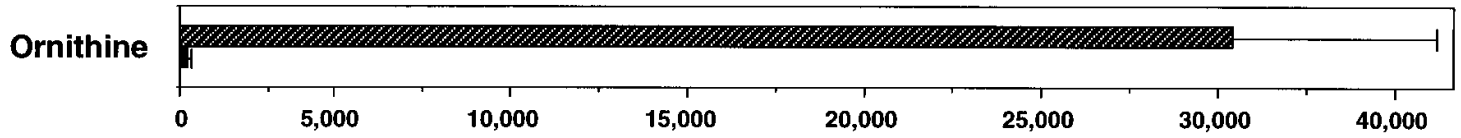

B

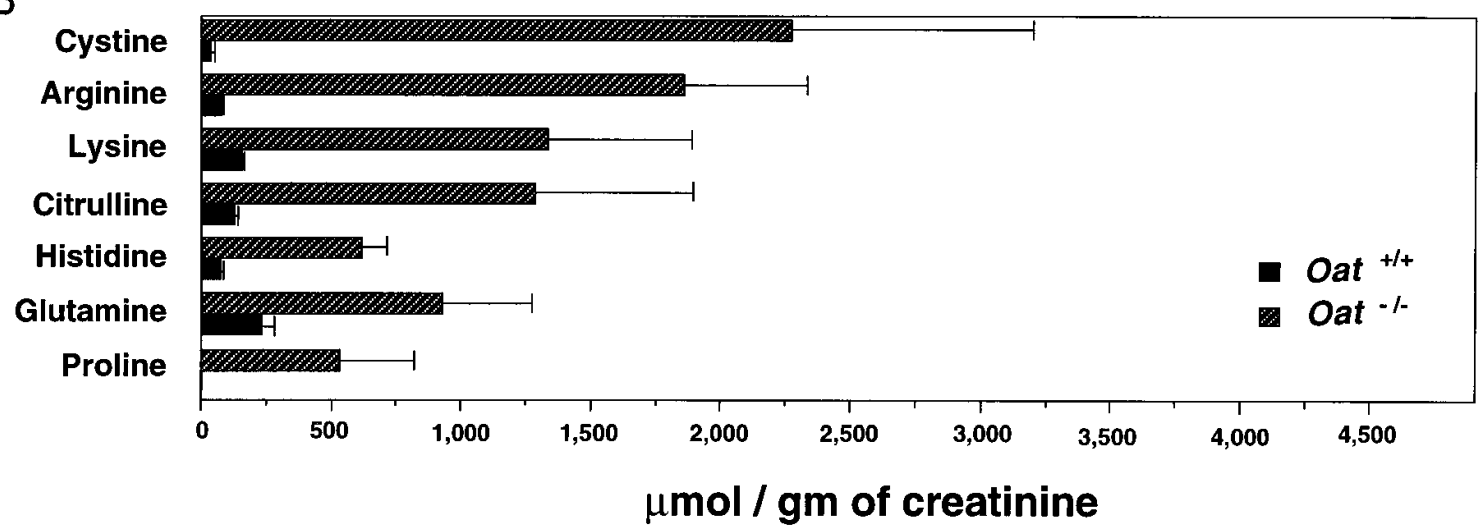

Figure 2. Selected urinary excretion of amino acids in adult $O a t^{+/+}$and $O a t^{-/-}$mice: $(A)$ ornithine; $(B)$ cystine, arginine, lysine, citrulline, histidine, glutamine, and proline. The mean and range for samples from four animals is indicated by a filled column and thin horizontal bars for $\mathrm{Oat}^{+/+}$ and by a shaded column and thin horizontal bars for $\mathrm{Oat}^{-/-}$mice.

thine values of $\mathrm{Oat}^{+/-}$and $\mathrm{Oat}^{+/+}$animals (data not shown). Parallel to the development of ornithine accumulation, plasma lysine decreases to values $\sim 50 \%$ those of littermate controls and remains stable thereafter (Fig. 1 B). Plasma arginine and citrulline normalize in the postweaning $\mathrm{Oat}^{-1-}$ animals (Fig. 1, $E$ and $F$ ). Plasma glutamate and glutamine in adult $\mathrm{Oat}^{-1-}$ mice and controls are comparable (Fig. 1, $C$ and $D$ ).

Urinary excretion of ornithine in the adult $\mathrm{Oat}^{-1-}$ mice is $>100$-fold that in controls (Fig. 2 A). The excretion of lysine and all other basic amino acids as well as citrulline, proline, and glutamine is also increased in these animals (Fig. 2 B). The excretion of all other neutral and acidic amino acids is normal (not shown).

Electrophysiology. We performed serial ERGs in a cohort of $\mathrm{Oat}^{-1-}$ mice and their littermate controls over the first 12 mo of life (Figs. 3 and 4). Fig. 3 A shows a typical ERG waveform recorded from a 10-mo-old $\mathrm{Oat}^{+/+}$mouse with a fast response downward (negative) A wave followed immediately by
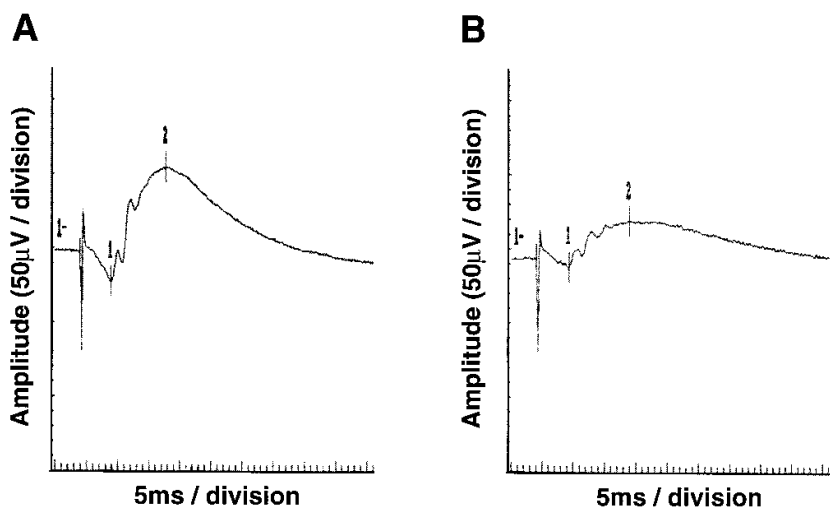

Figure 3. ERG of $\mathrm{Oat}^{+/+}$and $\mathrm{Oat}^{-/-}$mice at the age of $10 \mathrm{mo}$. Sample ERG waveforms for $\mathrm{Oat}^{+/+}(A)$ and $\mathrm{Oat}^{-/-}$mice $(B)$ aged 10 mo. ERG amplitude is measured as the difference between the peak of wave A (point 1) and the peak of wave B (point 2). a large upward B wave. Fig. $3 B$ shows an ERG waveform recorded from a 10-mo-old $\mathrm{Oat}^{-1-}$ mouse. The basic ERG waveform pattern is preserved but with a markedly depressed amplitude. Over the 12 mo of the study, the mean of the ERG amplitudes recorded from the control $\left(\mathrm{Oat}^{+/+}\right)$group was stable (Fig. 4). By contrast, the mean ERG amplitudes of the $\mathrm{Oat}^{-1-}$ mice gradually declined from normal levels at 2 mo to $\sim 40 \%$ of normal by 12 mo.

Retinal histopathology. The retinas of $\mathrm{Oat}^{-/-}$mice and their littermate controls were examined by light microscopy at ages $2,4,7$, and 10 mo and by electron microscopy at ages 2 and $7 \mathrm{mo}$. A pattern of slowly progressive retinal degeneration was observed, with the most severe pathology in the RPE and photoreceptor cells. The RPE and photoreceptor degeneration was most pronounced in the central superior and inferior regions of the retina with relative sparing of the photoreceptors adjacent to the optic nerve head and the ora serrata (Fig. 5, $A$ and $B$ ).

The RPE cells showed the earliest pathologic changes in the $\mathrm{Oat}^{-1-}$ mice. At $2 \mathrm{mo}$, compared with RPE cells in the control mice (Figs. $6 \mathrm{~A}$ and $7 \mathrm{~A}$ ), most RPE cells in the $\mathrm{Oat}^{-1-}$ animals had normal fine structure including their mitochondria (Fig. $6 \mathrm{~B}$ ), but occasional cells were necrotic with pale cytoplasm and swollen organelles (Fig. 7 B). Some melanin granules in the RPE cells were irregular in shape (Fig. $7 \mathrm{~B}$, inset), but the RPE cells were otherwise normal. The choriocapillaris and photoreceptors were also morphologically normal in the 2-mo-old $\mathrm{Oat}^{-1-}$ mice (Fig. $6 \mathrm{~B}$ ), although the outer segments were shorter than normal (see Fig. $10 \mathrm{~B}$ ).

At 7 mo, compared with normal mice (Fig. 8 A), the $\mathrm{Oat}^{-1-}$ mice showed pathologic changes in both the RPE and photoreceptors (Figs. 8, $B$ and $C$, and 9, $A-C$ ), and this was most severe in the central retina. Individual RPE cells were either swollen or flattened; most lacked basal infoldings and apical microvilli. Many RPE cells were engorged with phagocytosed outer segment membranes (Fig. 8, $B$ and $C$ ), and macrophages in the outer segment layer contained phagocytosed outer seg- 


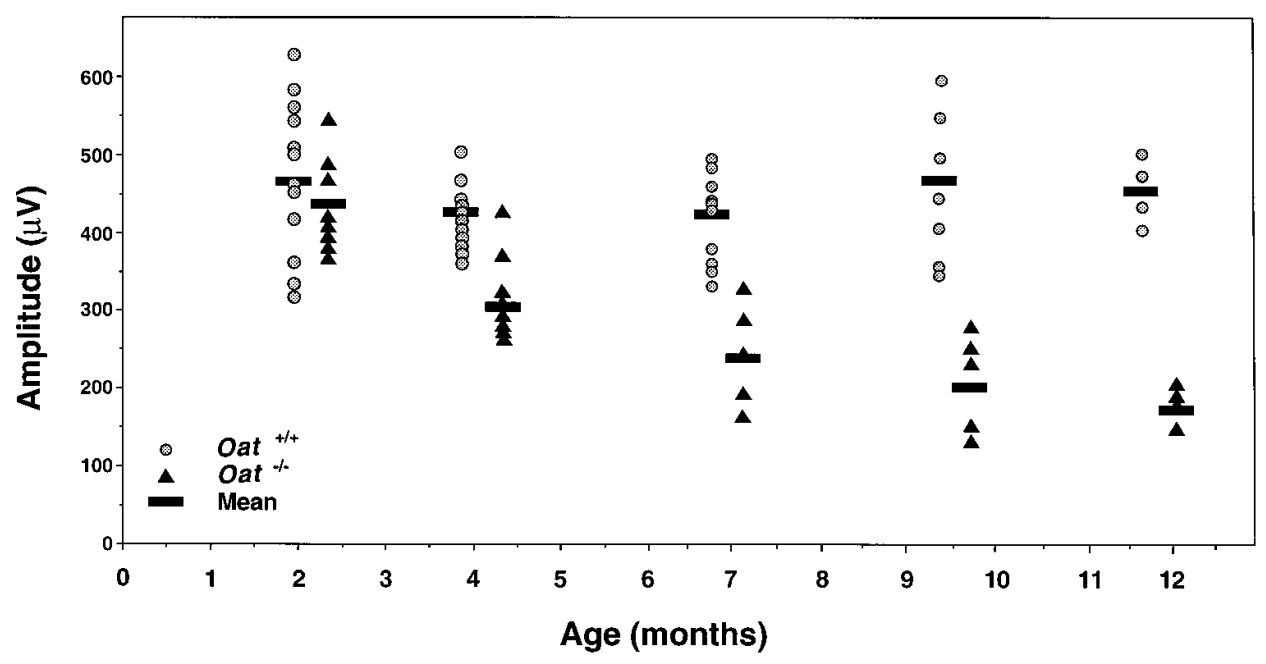

Figure 4. ERG amplitudes of $\mathrm{Oat}^{+/}$ ${ }^{+}$and $\mathrm{Oat}^{-1-}$ mice over 12 mo of life. Each filled circle represents the amplitude measured in an $\mathrm{Oat}^{+/+}$ mouse and each filled triangle represents the amplitude measured in an $\mathrm{Oat}^{-1-}$ mouse. The mean ERG amplitude for each age group is indicated by a filled horizontal bar. ments (Fig. $8 \mathrm{~B}$ ). The photoreceptor outer segments were markedly shortened and had lost their precise orientation; some of the membrane disks appeared dense and smudgy (Fig. $8 \mathrm{~B}$ ). Some photoreceptor mitochondria were swollen, but the choriocapillaris appeared normal at this age (Fig. $8 \mathrm{C}$ ).

Some of the RPE cells contained unusual inclusion bodies free in the cytoplasm (Fig. 9, $A-C$ ). Most of the inclusions contained homogenous material resembling lipid and were associated with $\sim 100$-nm tubule-like structures in the surrounding cytoplasm (Fig. 9 A). Other inclusions contained tubules within empty-appearing vacuoles (Fig. $9 B$ ) or tubules sur-

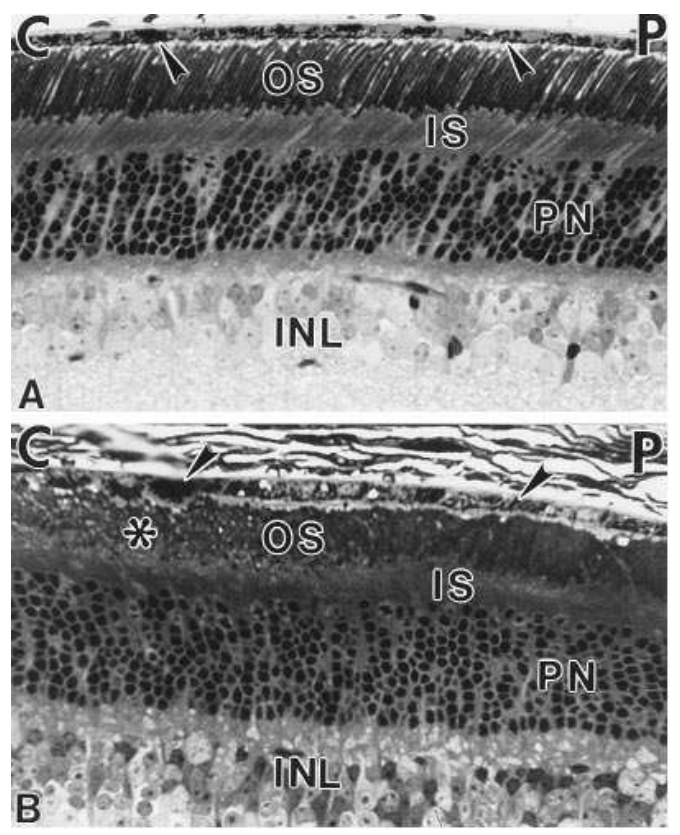

Figure 5. $(A)$ Central $(C)$ and peripapillary $(P)$ retina of 7-mo-old $\mathrm{Oat}^{+/+}$mouse, illustrating normal retinal pigment epithelium (arrowheads) and photoreceptors. OS, outer segments; IS, inner segments; $P N$, photoreceptor nuclei; $I N L$, inner nuclear layer. $\times 400$. (B) Central $(C)$ and peripapillary $(P)$ retina of a 7-mo-old $\mathrm{Oat}^{-1-}$ mouse. The retinal pigment epithelium (arrowheads) and photoreceptor outer segments $(O S)$ are degenerate (asterisk) in the central retina but have more normal morphology near the optic nerve head. IS, inner segments; $P N$, photoreceptor nuclei; $I N L$, inner nuclear layer. $\times 400$. rounded by the lipid-like material (Fig. 9 C). The identity of the inclusions is not known, but they did not appear to be derived from mitochondria, and normal-appearing mitochondria were present in the cytoplasm of the same RPE cells (Fig. 9, A and $B$ ).

The retinas of the $\mathrm{Oat}^{-1-}$ mice showed progressive loss of photoreceptors over the 10-mo period, with some overlap between animals of different ages in the control and $\mathrm{Oat}^{-1-}$ groups (Fig. 10, $A$ and $B$ ). Photoreceptor numbers were normal at 2 mo but then decreased slowly, showing an overall reduction by $\sim 33 \%$ at 10 mo (Fig. 10 A). Pyknotic photoreceptor nuclei were observed occasionally in the $\mathrm{Oat}^{-1-}$ mouse retinas at 4-10 mo but were not found in the control retinas. Very rare (five or fewer) TUNEL-positive nuclei were found in the flat-mounted 4- and 10-mo $\mathrm{Oat}^{-1-}$ hemiretinas (data not shown). Outer segment lengths in the $\mathrm{Oat}^{-1-}$ mice decreased

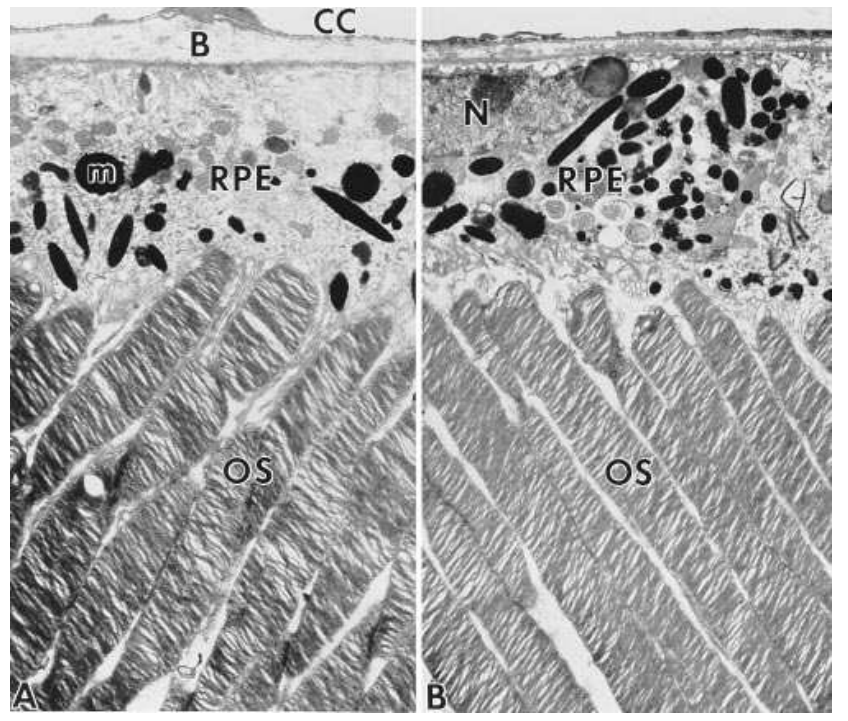

Figure 6. (A) 2-mo-old $\mathrm{Oat}^{+/+}$mouse retina, illustrating normal appearance of the RPE, Bruch's membrane $(B)$, choriocapillaris $(C C)$, and photoreceptor outer segments $(O S)$. $m$, melanin granule. $\times 7,500$. (B) 2-mo-old $\mathrm{Oat}^{-1-}$ mouse retina, illustrating normal-appearing RPE and photoreceptor outer segments $(O S)$. N, RPE nucleus. $\times 7,500$. 


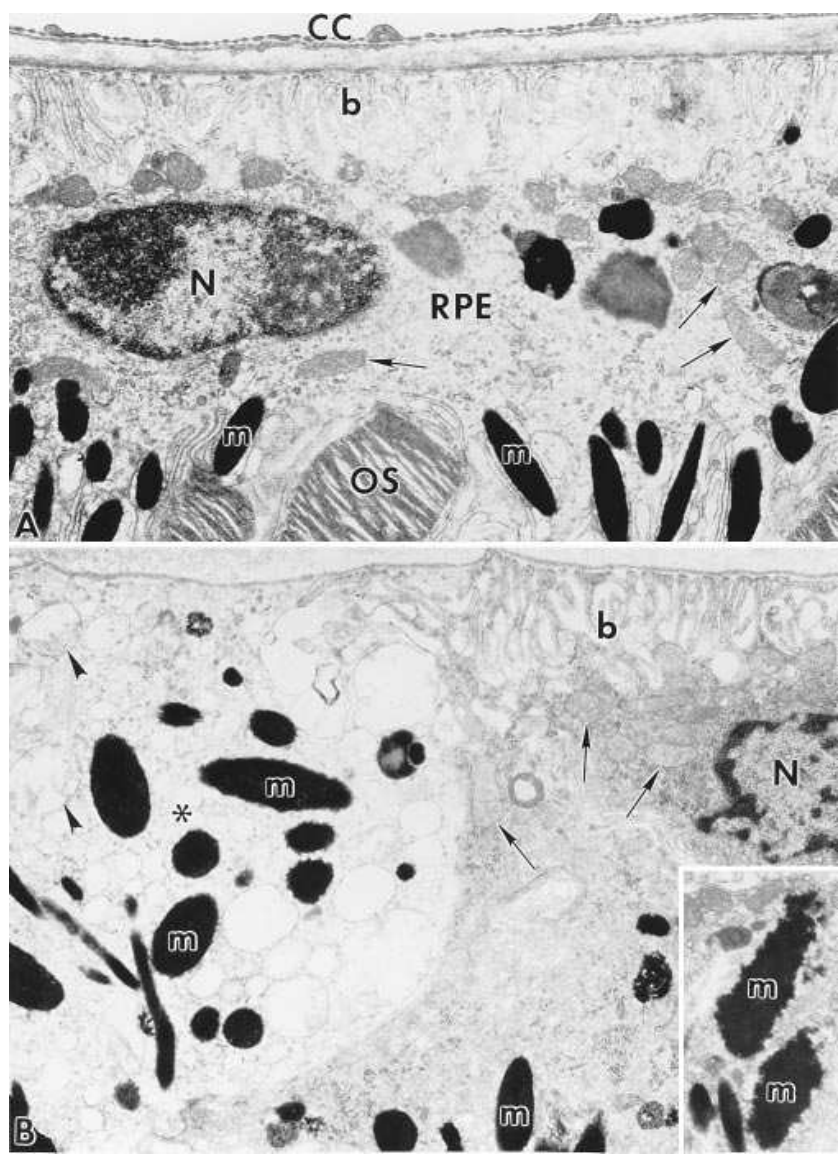

Figure 7. (A) High magnification of RPE from 2-mo-old $\mathrm{Oat}^{+/+}$ mouse, illustrating the basal infoldings $(b)$, fenestrated choriocapillaris $(C C)$, and photoreceptor outer segments $(O S)$. m, melanin granule; $N$, RPE nucleus; arrows, mitochondria. $\times 15,000$. (B) Retinal pigment epithelium cells from 2-mo-old $\mathrm{Oat}^{-1-}$ mouse. The cell on the right appears normal, including prominent basal infoldings $(b)$, whereas the cell on the left (asterisk) is necrotic with pale, extractedappearing cytoplasm and swollen mitochondria (arrowheads). $m$, melanin granule. $\times 15,000$. (Inset) Abnormally shaped melanin granules $(m)$ in retinal pigment epithelium of 2-mo-old $\mathrm{Oat}^{-/-}$mouse. $\times 15,000$.

progressively over time, and by 10 mo they were $<50 \%$ of the controls (Fig. 10 B).

Immunocytochemistry was used to localize several wellcharacterized proteins in the retinas of $\mathrm{Oat}^{+/+}$and $\mathrm{Oat}^{-1-}$ mice at ages 4 and $10 \mathrm{mo}$. In each animal, rhodopsin was present in the rod outer segments (Fig. 11, $A$ and $B$ ), which were noticeably shorter in the 4 - and 10 -mo-old $\mathrm{Oat}^{-/-}$mice (Fig. $11 \mathrm{~B}$ ). As noted in other retinal dystrophies that cause rod outer segment shortening (27), the $\mathrm{Oat}^{-1-}$ mice also showed delocalization of rhodopsin to the rod cell bodies (Fig. $11 B$ ). Red/green cone opsin showed normal distribution in the cone outer segments of all the retinas (Fig. 11, $C$ and $D$ ), but, like the rod outer segments, the cone outer segments were shorter in the $\mathrm{Oat}^{-1-}$ mice than in the controls (Fig. 11, A-D). In all of the mice, interphotoreceptor retinoid binding protein was localized to the interphotoreceptor matrix and cellular retinaldehyde binding protein was present in the cytoplasm of the RPE and retinal Müller cells (not shown). The macrophages in the outer segment layer of the 10-mo-old $\mathrm{Oat}^{-1-}$ mice were also la-
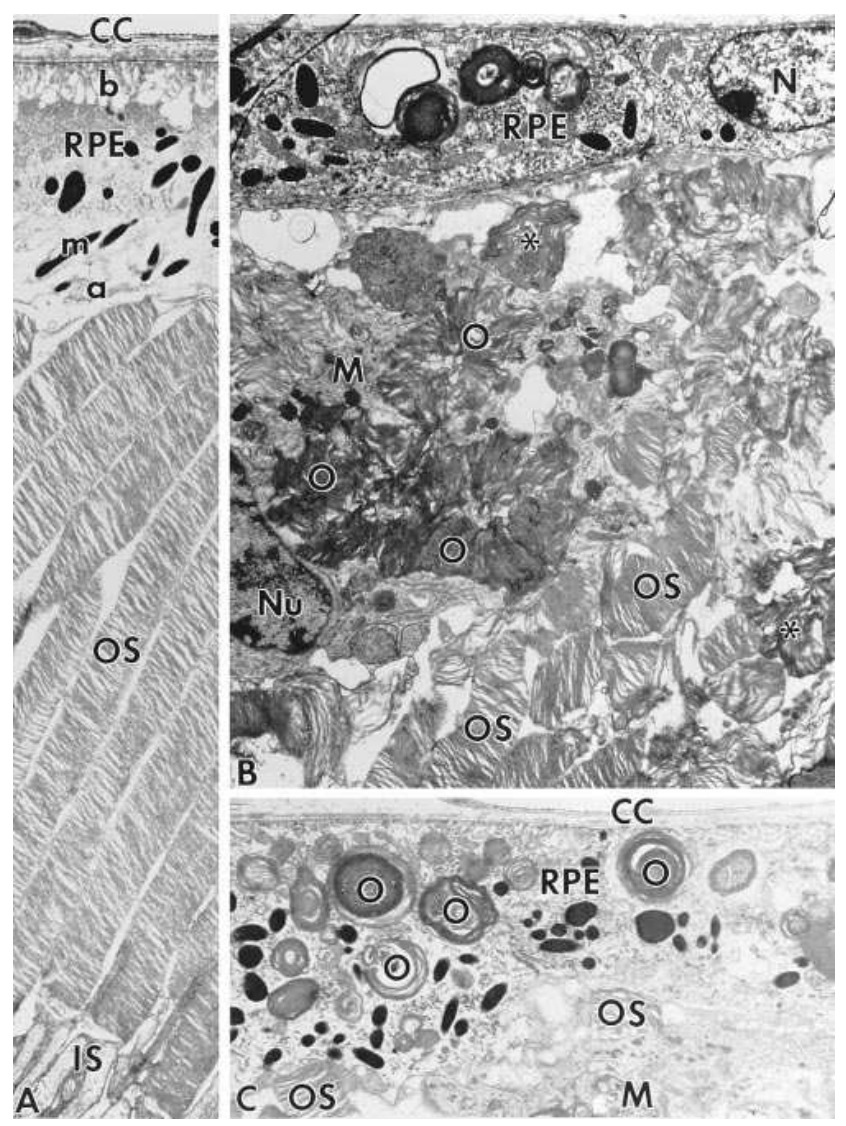

Figure 8. (A) 7-mo-old $\mathrm{Oat}^{+/+}$mouse retina, illustrating normal appearance of the RPE, photoreceptor outer segments $(O S)$, and inner segments (IS). a, apical microvilli of RPE cell; $m$, melanin granule; $b$, basal infoldings; $C C$, choriocapillaris. $\times 7,500$. (B) 7-mo-old Oat $^{-1-}$ mouse retina, illustrating pathologic changes in the RPE and photoreceptors. The photoreceptor outer segments (OS) are shortened and disorganized, and some (asterisk) show membrane densification. The RPE cells are flattened and have lost the apical microvilli and basal infoldings normally found. A macrophage $(M)$ in the outer segment layer contains phagocytosed outer segment membranes $(O)$. N, RPE nucleus; $\mathrm{Nu}$, macrophage nucleus. $\times 7,500$. (C) 7-mo-old $\mathrm{Oat}^{-1}$ mouse retina, illustrating engorgement of RPE with phagocytosed outer segment membranes $(O)$. The RPE cell basal infoldings are reduced and apical microvilli are absent. $C C$, fenestrated choriocapillaris; $O S$, photoreceptor outer segment; $M$, process of macrophage in outer segment layer. $\times 7,500$.

beled with anti-cellular retinaldehyde binding protein, suggesting that they were derived from the RPE. Glial fibrillary acidic protein was localized to the astrocytes in the innermost part of all the retinas (Fig. $11 \mathrm{E}$ ) and was also prominent in radial processes of the Müller cells in the retinas of the 4- and 10-mo $\mathrm{Oat}^{-1-}$ mice (Fig. $11 \mathrm{~F}$ ), consistent with a gliotic response to ongoing cell death in the retinas of these animals (29).

\section{Discussion}

The $\mathrm{Oat}^{-/-}$mice we have produced by gene targeting have no detectable OAT activity and a metabolic phenotype that is remarkably similar to that of GA patients (14). In both, plasma ornithine concentrations are 10-15-fold higher and plasma 


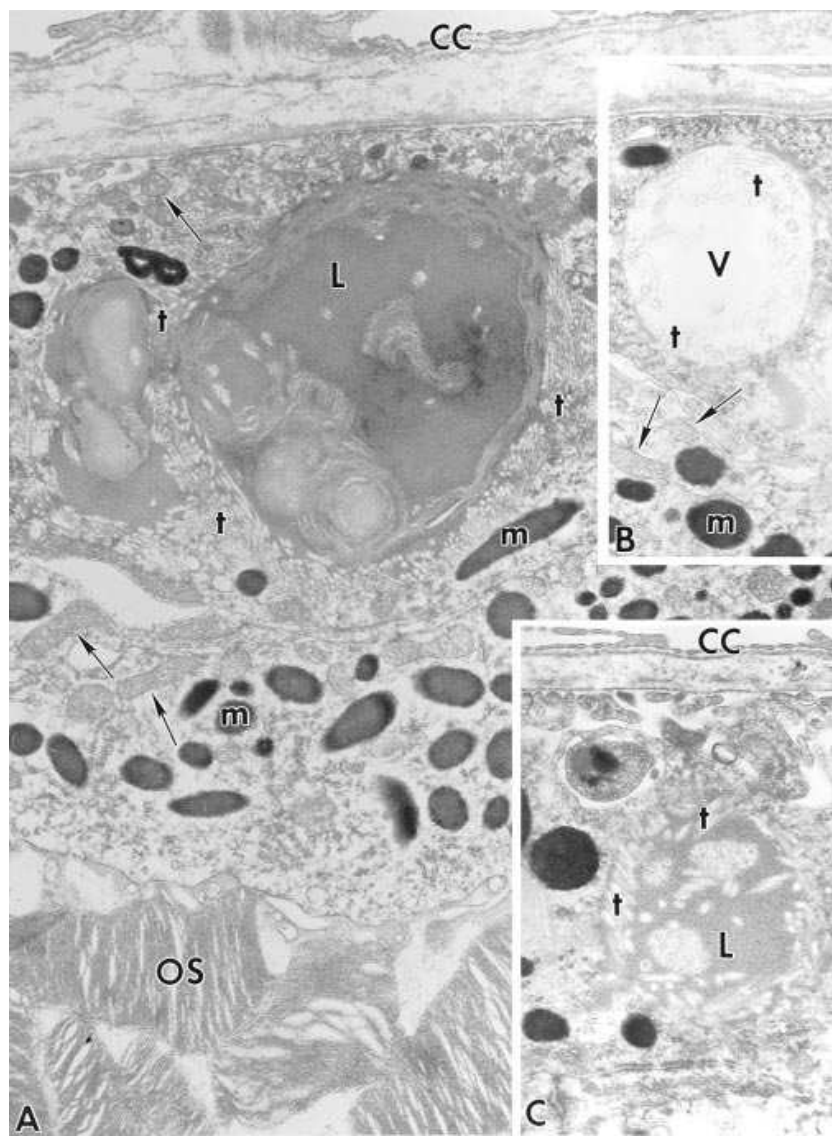

Figure 9. (A) Retinal pigment epithelium cell as in Fig. 8, $B$ and $C$. Note the large inclusion body, which contains lipid-like material $(L)$ and is surrounded by $\sim 100$-nm tubule-like structures $(t)$ in the cytoplasm. $m$, melanin granule; arrows, normal-appearing mitochondria; $C C$, choriocapillaris; $O S$, outer segment. $\times 16,000$. (B) Retinal pigment epithelium cell as in Fig. 9 A. Note the large inclusion, which contains $\sim 100$-nm tubules $(t)$ in an empty-appearing vacuole $(V)$. Arrows, normal-appearing mitochondria. $\times 20,000$. (C) Retinal pigment epithelium cell as in Fig. 9, $A$ and $B$. A large inclusion body contains tubules $(t)$ surrounded by a lipid-like $(L)$ matrix. $C C$, choriocapillaris. $\times 20,000$.

lysine concentrations $\sim 50 \%$ lower than those of controls. As in humans, the magnitude of the ornithine accumulation in the $\mathrm{Oat}^{-1-}$ mice is constant into old age $(14,30)$. The reduction in lysine levels, characteristic of both $\mathrm{Oat}^{-1-}$ mice and humans, is thought to result from decreased renal tubular reabsorption of lysine due to overflow ornithinuria (14). In agreement with this model, we found increased urinary excretion of ornithine, lysine, and all other basic amino acids in $\mathrm{Oat}^{-1-}$ mice. Similar observations have been reported in human GA patients (14).

The loss of retinal function in the $\mathrm{Oat}^{-1-}$ mice is a slow and cumulative process but occurs over a much shorter absolute time span than in humans. In human GA patients, the ERG amplitude decreases gradually and is usually undetectable by the end of the second decade of life, at a time when there is still normal-appearing retina in the posterior pole $(5,30)$. The mean ERG amplitude in the $\mathrm{Oat}^{-1-}$ mice is normal at 2 mo of age but declines slowly to $\sim 40 \%$ of normal by the end of $1 \mathrm{yr}$. This time course correlates well with the histopathological changes in the retinas. Although the retinas of the 2-mo-old $\mathrm{Oat}^{-1-}$ mice were near normal in morphology, subtle changes were detected in scattered RPE cells, including swelling and loss of basal infoldings and apical processes. The photoreceptor outer segments were somewhat shortened by 2 mo and became progressively shorter over the ensuing month. By 7 mo, the RPE cells in the central retina were markedly abnormal, including cellular swelling and flattening, loss of basal and apical specializations, and engorgement with phagocytosed outer segment membranes. The photoreceptor outer segments also had abnormal fine structure at this time, including misalignment and membrane densification. In addition to phagocytosis of outer segment membranes by the RPE cells in situ, some outer segment debris that appeared to be derived from the RPE was ingested by macrophages. The time course of pathology in the RPE and photoreceptors is consistent with an initial loss of function in the RPE and secondary loss of normal structure and presumably function in the photoreceptors. Additionally, the fine structural changes in the outer segments and prominent phagocytosis of outer segment membranes by the RPE closely resemble the cytopathologic changes in these cells after experimental light damage to the retina (31). This suggests that the metabolic alterations produced by OAT deficiency rendered the photoreceptor outer segments more susceptible to damage from the normal light levels under which these mice were reared.

Mitochondrial abnormalities have been noted in a variety of cell types in human GA patients including hepatocytes, muscle cells, corneal endothelial cells and keratocytes, ciliary epithelial cells, and rod photoreceptors $(9,20,32)$. Some swollen mitochondria were found in the degenerate $\mathrm{Oat}^{-1-}$ photoreceptors, but the RPE mitochondria in the $\mathrm{Oat}^{-/-}$mice had normal fine structure, in agreement with the finding of normal appearing mitochondria in the RPE of a human GA patient (20). Some RPE cells in the $\mathrm{Oat}^{-1-}$ mice contained unusual inclusions comprised of $\sim 100$-nm tubules in a matrix of lipidlike material. To our knowledge, comparable inclusions have not previously been reported in RPE cells. These novel structures are presumably related to metabolic abnormalities in the RPE cells, but their significance is unknown.

One phenotypic difference between $\mathrm{Oat}^{-1-}$ mice and humans is the geographic distribution of the retinal degeneration. In the mice, the early stage of retinal degeneration predominately involves the central superior and inferior regions of the retina, whereas retinal degeneration in GA patients initially begins in the midperiphery (4). Although the reason for this discrepancy is not known, it may relate to the differences in photoreceptor distribution between the two species, including a relative paucity of cones and the absence of a macula in the murine retina (33). As in certain other inherited retinal dystrophies (34), a nonuniform pattern of degeneration of photoreceptors across the retina suggests that other factors in addition to the specific gene mutation are important in producing the final disease phenotype (35). The regional pattern of photoreceptor degeneration in the $\mathrm{Oat}^{-1-}$ mice resembles the patterns found in other toxic and inherited conditions in which the RPE cells are the primary site of pathology, including the Royal College of Surgeons rat (26), vitiligo mice (36), and the retinopathy produced by iodoacetate administration in cats and rabbits (37). In each of these pathologic conditions, photoreceptors in the central retina are more severely affected than those in the periphery, and there is relative sparing of the photoreceptors in the region just adjacent to the optic nerve head, as observed here. 

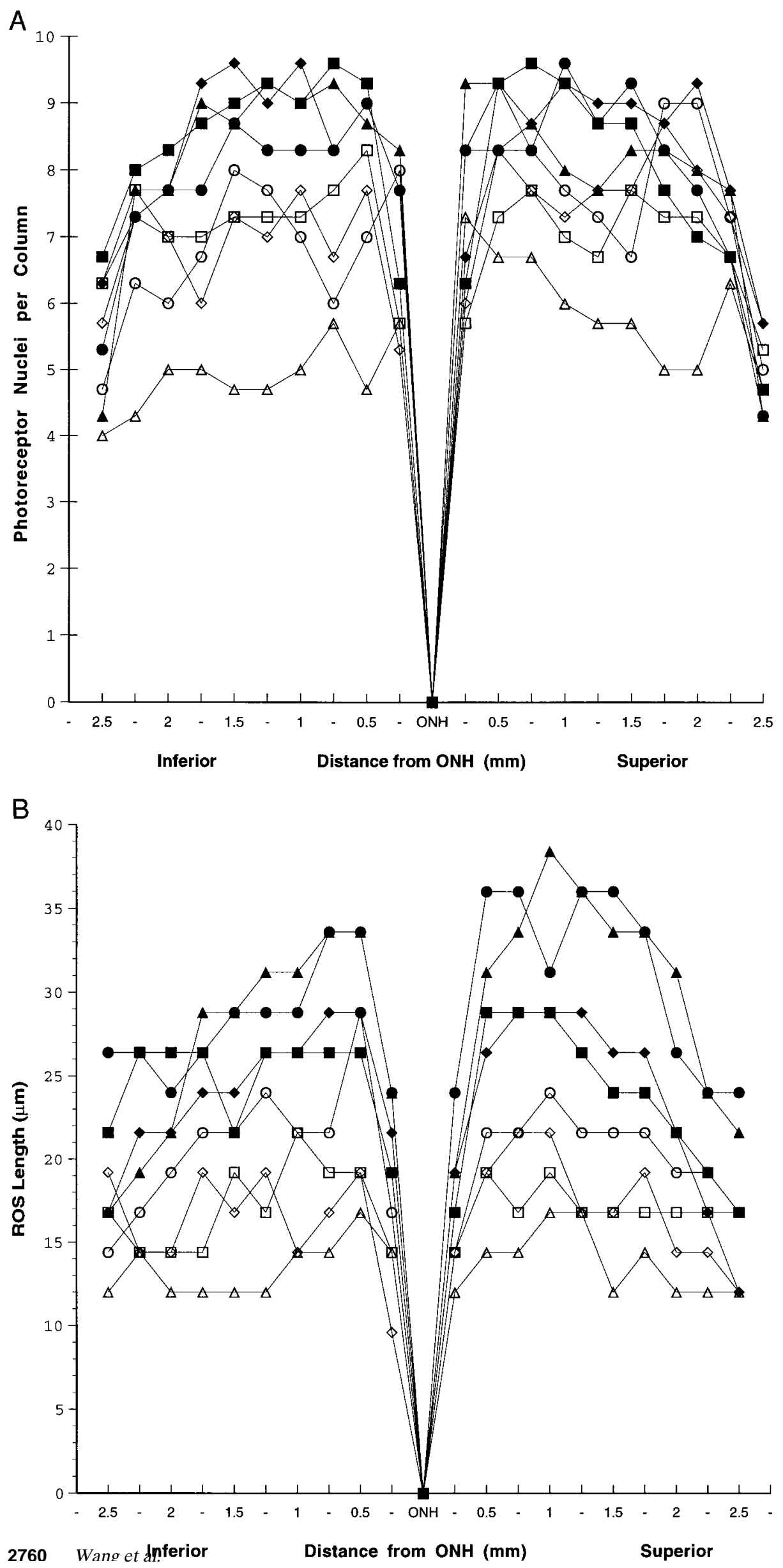

Figure 10. (A) Counts of photoreceptor cells at different ages in $\mathrm{Oat}^{+/+}$and $O a t^{-/-}$mice. Photoreceptor nuclei were counted per column of cells in the outer nuclear layer at adjacent $250 \mu \mathrm{m}$ points along the vertical meridian in the superior and inferior retina. Each point represents the mean of three counts. Filled symbols indicate $\mathrm{Oat}^{-1-}$ mice, and open symbols indicate $\mathrm{Oat}^{+/+}$littermates at the following ages: squares, 2 mo; circles, $4 \mathrm{mo}$; diamonds, $7 \mathrm{mo}$; triangles, $10 \mathrm{mo}$. $\mathrm{ONH}$, optic nerve head. (B) Photoreceptor outer segment lengths at different ages in $\mathrm{Oat}^{+/+}$and $\mathrm{Oat}^{-/-}$mice. Outer segments were measured at adjacent 250 $\mu \mathrm{m}$ points along the vertical meridian in the superior and inferior retina. Each point represents the mean of three measurements. ROS, rod outer segment; $\mathrm{ONH}$, optic nerve head. 

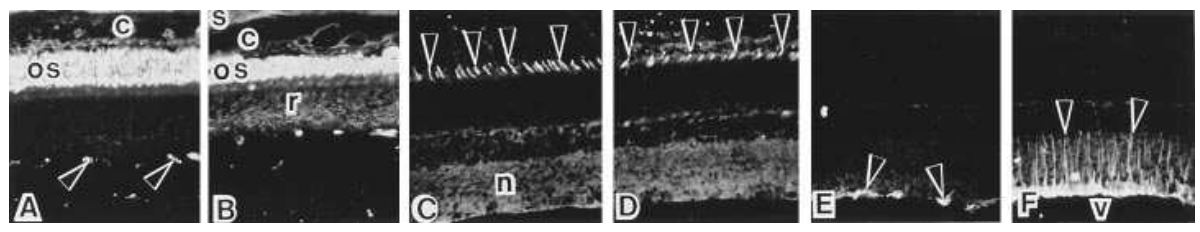

Figure 11. (A) Immunofluorescent localization of rhodopsin in retina from 4-mo-old $\mathrm{Oat}^{+/+}$mouse. Specific labeling is restricted to the layer of outer segments (os). Arrowheads indicate autofluorescent erythrocytes in the retinal blood vessels. c, choroid. $\times 140$. (B) Retina of 4-mo-old $\mathrm{Oat}^{-1-}$ mouse processed as in Fig. $11 \mathrm{~A}$.

The outer segments (os) show immunolabeling with antirhodopsin but are shorter than normal. The rod cell bodies ( $r$ ) show delocalized rhodopsin labeling. The sclera (s) shows nonspecific autofluorescence. $c$, choroid. $\times 140$. (C) Immunofluorescent localization of red/green cone opsin in retina from 4-mo-old $\mathrm{Oat}^{+/+}$mouse. Specific labeling is restricted to the cone outer segments (arrowheads). The inner layers of the neurosensory retina (n) show nonspecific background labeling. $\times 140$. (D) Retina of a 4-mo-old Oat ${ }^{-1-}$ mouse processed as in Fig. $11 C$. The cone outer segments (arrowheads) are well labeled with anti-red/green cone opsin but are shorter than normal. $\times 140$. (E) Immunofluorescent localization of glial fibrillary acidic protein in retina from a 4-mo-old $\mathrm{Oat}^{+/+}$mouse. Specific labeling is present in the astrocytes (arrowheads) in the innermost part of the retina. $\times 140$. (F) Retina of 4-mo-old $\mathrm{Oat}^{-1-}$ mouse processed as in Fig. $11 \mathrm{E}$. In addition to astrocytic labeling, the Müller glial cell radial processes (arrowheads) are strongly labeled, consistent with ongoing death of retinal cells. $v$, vitreous cavity. $\times 140$.

As in GA patients, there is some variability in the rate of retinal degeneration among $\mathrm{Oat}^{-1-}$ mice, suggesting that unrecognized variables in addition to OAT deficiency and ornithine accumulation influence the disease phenotype. The hybrid genetic background in these mice (a mix of 129 and $\mathrm{C} 57 \mathrm{Bl} / 6$ strains) may also contribute to the individual variability observed. If this is correct, breeding the targeted OAT allele onto pure strain 129 and strain $\mathrm{C} 57 \mathrm{Bl} / 6$ animals should yield strains of mice with different rates of progression of retinal degeneration and provide a system for identifying genes responsible for these phenotypic differences $(38,39)$.

In this study we provide histopathologic evidence that the RPE is likely the initial site of insult in GA. Indirect evidence for initial damage to the RPE in human GA includes early fluorescein angiographic abnormalities $(4,40)$ and the ERG demonstration of loss of the RPE-derived $\mathrm{C}$ wave in one patient with detectable A and B waves (5). Abnormal RPE cells were noted in the only histopathologic report in a human with GA, a 98 -yr-old vitamin $\mathrm{B}_{6}$-responsive patient (20). In this patient, the retina in the posterior pole was normal appearing, and, near the transition from relatively normal to atrophic retina in the periphery, there were areas where the RPE was flattened with loss of apical microvilli and basal infoldings, as found in the older $\mathrm{Oat}^{-1-}$ mice. The RPE is important for photoreceptor nutrition and is specialized for phagocytosis and degradation of photoreceptor outer segments (41). RPE cells are connected by tight junctions at their apical lateral surfaces and constitute the outer blood-retinal barrier (42). The accumulated outer segment debris in the subretinal space of the Oat ${ }^{-1-}$ mice may interfere with these RPE functions and contribute to the slow, progressive loss of photoreceptors. Also, the breakdown of the blood-retinal barrier at an advanced stage of GA may expose the photoreceptor cells to harmful agents from the choroidal circulation, accelerating the process of retinal degeneration.

The mechanism(s) by which OAT deficiency and ornithine accumulation cause RPE degeneration remains to be elucidated. OAT is expressed at high levels in the RPE and at lower levels in the photoreceptors (43-47). A priori, RPE damage could result from local OAT deficiency or from special sensitivity of the RPE to ornithine accumulation. Evidence from patients with inborn errors of ornithine metabolism does not discriminate between these two possibilities (14). Patients with the hyperornithinemia-hyperammonemia-homocitrullinuria syndrome have normal retinas and OAT activity but accumu- late ornithine to levels nearly as high as those in GA (14). The defect is thought to be due to impaired ornithine transport into mitochondria. However, in GA patients in whom ornithine levels are chronically reduced by ingestion of an argininerestricted diet, retinal degeneration appears to slow or even cease (48). This observation, although based on a small number of patients, suggests that ornithine accumulation plays an essential role in the disease process. The availability of $\mathrm{Oat}^{-/-}$ mice should allow direct investigation of these potential pathophysiologic mechanisms.

\section{Acknowledgments}

We thank J. Chang, I. Klock, and D. Possin for assistance with retinal histopathology; C. Stephens for photographic help; Drs. R. Molday and J. Saari for gifts of antibodies; and S. Muscelli for preparing this manuscript.

This work was supported in part by National Eye Institute grants EY02948 (D. Valle), EY01311 and EY01730 (A.H. Milam); The Foundation Fighting Blindness (D. Valle and A.H. Milam); Research to Prevent Blindness, Inc. (A.H. Milam); and by National Institute of Child Health and Human Development Mental Retardation Research Center grant HD24605 (D. Valle). D. Valle is an Investigator and T. Wang is a Research Associate with the Howard Hughes Medical Institute.

\section{References}

1. Jacobsohn, E. 1888. Ein fall von Retinitis pigmentosa atypica. Klin. Monatsbl. Augenheilkd. 26:202-206.

2. Takki, K., and R. Milton. 1981. The natural history of gyrate atrophy of the choroid and retina. Ophthalmology. 88:292-301.

3. Francois, J. 1979. Gyrate atrophy of the choroid and retina. J. Ophthalmologica (Basel). 178:311-320.

4. Kaiser-Kupfer, M., I. Ludwig, F. DeMonasterio, D. Valle, and I. Krieger 1985. Gyrate atrophy of the choroid and retina. Early findings. Ophthalmology. 92:394-401.

5. Takki, K., and O. Simell. 1974. Genetic aspects in gyrate atrophy of the choroid and retina with hyperornithinemia. Br. J. Ophthalmol. 58:907-916.

6. Raitta, C., S. Carlson, and K. Vannas-Sulonen. 1990. Gyrate atrophy of the choroid and retina: ERG of the neural retina and the pigment epithelium. Br. J. Ophthalmol. 74:363-367.

7. Weleber, R.G., and N.G. Kennaway. 1988. Gyrate atrophy of the choroid and retina. In Retinitis Pigmentosa. J.R. Heckenlively, editor. J.B. Lippincott Co., Philadelphia. 198-220.

8. Simell, O., and K. Takki. 1973. Raised plasma ornithine and gyrate atrophy of the choroid and retina. Lancet. i:1031-1033.

9. McCulloch, J., S. Arshinoff, E. Marliss, and J. Parker. 1978. Hyperornithinemia and gyrate atrophy of the choroid and retina. Ophthalmology. 85:918-928.

10. Takki, K., and O. Simell. 1976. Gyrate atrophy of the choroid and retina with hyperornithinemia. Birth Defects Orig. Artic. Ser. 12:373-384.

11. Kennaway, N., R. Weleber, and N. Buist. 1980. Gyrate atrophy of the 
choroid and retina with hyperornithinemia. Biochemical and histologic studies and response to vitamin B6. Am. J. Hum. Genet. 32: 529-541.

12. Valle, D., M. Walser, S. Brusilow, and M. Kaiser-Kupfer. 1980. Gyrate atrophy of the choroid and retina: Amino acid metabolism and correction of hyperornithinemia with an arginine deficient diet. J. Clin. Invest. 65:371-378

13. Valle, D., M. Walser, S. Brusilow, M. Kaiser-Kupfer, and K. Takki. 1981. Gyrate atrophy of the choroid and retina. Biochemical considerations and experience with an arginine-restricted diet. Ophthalmology. 88: 325-330.

14. Valle, D., and O. Simell. 1995. The hyperornithinemias. In The Metabolic and Molecular Bases of Inherited Disease. C. Scriver, A. Beaudet, W. Sly, and D. Valle, editors. McGraw Hill Inc., New York. 1147-1185.

15. Kaiser-Kupfer, M., and D. Valle. 1986. Clinical, biochemical and therapeutic aspects of gyrate atrophy. In Progress in Retinal Research. N. Osbourne and J. Chader, editors. Pergamon, Oxford. 179-206.

16. Mitchell, G., J. Looney, L. Brody, G. Steel, M. Suchanek, J. Engelhardt, H. Willard, and D. Valle. 1988. Human ornithine- $\delta$-aminotransferase: cDNA cloning and analysis of the structural gene. J. Biol. Chem. 263:14288-14295.

17. Ramesh, V., M. Shaffer, J. Allaire, V. Shih, and J. Gusella. 1986. Investigation of gyrate atrophy using a cDNA clone for human ornithine aminotransferase. DNA (NY). 5:493-501.

18. Inana, G., S. Totsuks, M. Redmond, T. Dougherty, J. Nagle, R. Shiono, T. Ohura, E. Kominami, and N. Katunuma. 1986. Molecular cloning of human aminotransferase mRNA. Proc. Natl. Acad. Sci. USA. 83:1203-1207.

19. Brody, L.C., G.A. Mitchell, C. Obie, J. Michaud, G. Steel, G. Fontaine, M.-F. Robert, M.I. Kaiser-Kupfer, and D. Valle. 1992. Ornithine- $\delta$-aminotransferase mutations causing gyrate atrophy: allelic heterogeneity and functional consequences. J. Biol. Chem. 267:3302-3307.

20. Wilson, D.J., R.G. Weleber, and W.R. Green. 1991. Ocular clinicopathologic study of gyrate atrophy. Am. J. Ophthalmol. 111:24-33.

21. Valle, D., A. Boison, J. Jezyk, and G. Aguirre. 1981. Gyrate atrophy of the choroid and retina in a cat. Invest. Ophthalmol. \& Visual Sci. 20:251-255.

22. Daune-Anglard, G., N. Bonaventure, and N. Seiler. 1993. Some biochemical and pathophysiological aspects of long-term elevation of brain ornithine concentrations. Pharmacol. \& Toxicol. 73:29-34.

23. Wang, T., A.M. Lawler, G. Steel, I. Sipila, A.H. Milam, and D. Valle. 1995 . Mice lacking ornithine- $\delta$-aminotransferase have paradoxical neonatal hypoornithinaemia and retinal degeneration. Nat Genet. 11:185-190.

24. Hauser, E.R., J. Finkelstein, D. Valle, and S.W. Brusilow. 1990. Allopurinol-induced orotidinuria: a test for mutations at the ornithine transcarbamylase locus in women. N. Engl. J. Med. 322:1641-1645.

25. Hamasaki, D.I., R.D. Dix, and S.S. Atherton. 1988. Bilateral alterations of the ERG and retinal histology following unilateral HSV inoculation. Invest. Ophthalmol. \& Visual Sci. 29:1242-1254.

26. LaVail, M.M., and B.-A. Battelle. 1975. Influence of eye pigmentation and light deprivation on inherited retinal dystrophy in the rat. Exp. Eye Res. 21: $167-192$

27. Li, Z.-Y., I.J. Kljavin, and A.H. Milam. 1995. Rod photoreceptor neurite sprouting in retinitis pigmentosa. J. Neurosci. 15:5429-5438.

28. Gavrieli, Y., Y. Sherman, and S.A. Ben-Sasson. 1992. Identification of programmed cell death in situ via specific labeling of nuclear DNA fragments. J. Cell Biol. 119:493-501.

29. Eisenfeld, A.J., A.H. Bunt-Milan, and P.V. Sarthy. 1984. Müller cell expression of glial fibrillary acidic protein after genetic and experimental photoreceptor degeneration in the rat retina. Invest. Ophthalmol. \& Visual Sci. 25: 1321-1328.
30. Takki, K. 1974. Gyrate atrophy of the choroid and retina associated with hyperornithinemia. Br. J. Ophthalmol. 58:3-7.

31. Kuwabara, T. 1979. Photic and photo-thermal effects on the retinal pigment epithelium. In The Retinal Pigment Epithelium. K.M. Zinn and M.F. Marmor, editors. Harvard University Press, Cambridge, MA. 293-313.

32. Vannas Sulonen, K., A. Vannas, J. O'Donnell, I. Sipila, and I. Wood. 1983. Pathology of iridectomy specimens in gyrate atrophy of the retina and choroid. Acta Ophthalmol. 61:9-19.

33. Carter-Dawson, L.D., and M.M. LaVail. 1979. Rods and cones in the mouse retina. I. Structural analysis using light and electron microscopy. $J$. Comp. Neurol. 188:245-262.

34. Li, Z.-Y., S.G. Jacobson, and A.H. Milam. 1994. Autosomal dominant retinitis pigmentosa caused by the threonine-17-methionine rhodopsin mutation: retinal histopathology and immunocytochemistry. Exp. Eye Res. 58:397408

35. Papermaster, D.S. 1995. Necessary but insufficient. Nat. Med. 1:874875

36. Nir, I., N. Ransom, and S.B. Smith. 1995. Ultrastructural features of retinal dystrophy in mutant vitiligo mice. Exp. Eye Res. 61:363-377.

37. Noell, W.K. 1952. The impairment of visual cell structure by iodoacetate. J. Cell. Comp. Physiol. 40:25-55.

38. Frankel, W.N. 1995. Taking stock of complex trait genetics in mice. Trends Genet. 11:471-476.

39. Smithies, O., and N. Maeda. 1995. Gene targeting approaches to complex genetic diseases: atherosclerosis and essential hypertension. Proc. Natl. Acad. Sci. USA. 92:5266-5272.

40. Vannas Sulonen, K. 1987. Progression of gyrate atrophy of the choroid and retina: a long-term follow-up by fluorescein angiography. Acta Ophthalmol. 65:101-109.

41. Steinberg, R.H., and I. Wood. 1979. The relationship of the retinal pigment epithelium to photoreceptor outer segments in human retina. In The Retinal Pigment Epithelium. K.M. Zinn and M.F. Marmor, editors. Harvard University Press, Cambridge, MA. 32-44.

42. Steinberg, R.H., and S.S. Miller. 1979. Transport and membrane properties of the retinal pigment epithelium. In The Retinal Pigment Epithelium. K.M. Zinn and M.F. Marmor, editors. Harvard University Press, Cambridge, MA. 205-225.

43. Ratzlaff, K., and A. Batch. 1987. Comparison of ornithine activities in the pigment epithelium and retina of vertebrates. Comp. Biochem. Physiol. 88B:35.

44. Hayakasa, S., T. Shiono, Y. Takaku, and K. Mizuno. 1980. Ornithine ketoacid aminotransferase in the bovine eye. Invest. Ophthalmol. 19:1457-1460.

45. Rao, G., and E. Cotler. 1984. Ornithine delta-aminotransferase activity in retina and other tissues. Neurochem. Res. 9:555-562.

46. Kasahara, M., T. Matsuzawa, M. Kokubo, Y. Gushiken, K. Tashiro, T. Koide, H. Watanabe, and N. Katanuma. 1986. Immunohistochemical localization of ornithine aminotransferase in normal rat tissues by Fab' horseradish peroxidase conjugates. J. Histochem. Cytochem. 34:1385-1388.

47. Takahashi, O., S.-I. Ishiguro, T. Mito, S. Hayasaka, T. Shiono, K. Mizuno, T. Ohura, and K. Tada. 1987. Immunocytochemical localization of ornithine aminotransferase in rat ocular tissues. Invest. Ophthalmol. Visual Sci. 28: 1617-1619.

48. Kaiser-Kupfer, M., R. Caruso, and D. Valle. 1991. Gyrate atrophy of the choroid and retina: chronic reduction of ornithine slows retinal degeneration. Arch. Ophthalmol. 109:1539-1548. 